\title{
ORALIDADE, MEMÓRIA E A MEDIAÇÃO DO OUTRO: PRÁTICAS DE LETRAMENTO ENTRE SUJEITOS COM BAIXOS NÍVEIS DE ESCOLARIZAÇÃO - O CASO DO CORDEL (1930-1950)*
}

\author{
Ana Maria de Oliveira Galvão*
}

\begin{abstract}
RESUMO: $\mathrm{O}$ artigo propõe-se a discutir quais as especificidades da relação que sujeitos vinculados, em sua origem, a uma cultura em que a oralidade é predominante estabelecem com a cultura escrita. Essa discussão é realizada a partir dos resultados de uma pesquisa concluída que teve como objetivo (re)construir o público leitor/ouvinte e os modos de ler/ouvir literatura de cordel entre 1930 e 1950 em Pernambuco. Pode-se considerar que vários fatores, destacando-se a leitura em voz alta, intensiva e coletiva e o papel desempenhado pela memorização, facilitada pelas situações de leitura e pela própria estrutura narrativa e formal dos poemas, contribuíam para que as relações entre analfabetos e semi-alfabetizados e a leitura de folhetos fossem marcadas pelo prazer e por um relativo desprendimento. Essas práticas permitiam a pessoas que, em sua origem, estavam pouco habituadas ao mundo da escrita, vivenciarem práticas de letramento, ou seja, experimentarem situações em que utilizavam as palavras escrita e impressa.
\end{abstract}

Palavras-chave: Folhetos de cordel. Letramento. Oralidade. Memorização. História da leitura.

* Tomo aqui, a palavra letramento em um sentido amplo, considerada, sobretudo, como “(...) o estado ou a condição que adquire um grupo social ou um indivíduo como conseqüência de ter-se apropriado da escrita” (Soares, 1998, p. 18). A partir desse ponto de vista, um sujeito, mesmo sendo analfabeto, pode, em alguns casos, ser considerado, de certa forma, letrado, na medida em que o mais importante, no conceito, são os usos da escrita feitos pelos sujeitos.

** Professora do Centro de Educação da Universidade Federal de Pernambuco (UFPE); mestra e doutora em Educação pela Universidade Federal de Minas Gerais (UFMG). E-mail: anagalvao@nlink.com.br

Educ. Soc., Campinas, vol. 23, n. 81, p. 115-142, dez. 2002

Disponível em <http://www.cedes.unicamp.br> 
ORALITY, MEMORY AND THE MEDIATION OF THE OTHER: LITERACY PRACTICES BETWEEN SUBJECTS WITH LOW SCHOOLING LEVELS - THE CORDEL CASE (1930-1950)

ABSTRACT: This paper discusses the specificities of the relationship that subjects deeply rooted in a predominantly oral culture establish with the written language. It uses the results of a completed research aimed at retracing the reading/listening public and the different forms of listening to/reading cordel literature between 1930 and 1950 in Pernambuco. It is argued that several factors, mainly reading aloud, intensively and collectively, and the role of memorization, favored by the reading situations and the narrative and formal structure of the very poems, made the relations between both illiterates and semi-literates and the reading of cordel enjoyable and relaxed. Such practices allowed people who, originally, were not very familiar with the reading world to experience literacy practices, that is, to experience situations where they used printed words.

Key words: Cordel literature. Literacy. Oral language. Memorization. History of reading.

\section{Introdução}

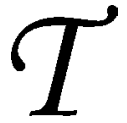

radicionalmente, as pesquisas que tomam por objeto a história da cultura escrita no Brasil tendem a considerar, como mediadores fundamentais para a inserção de indivíduos, famílias e grupos sociais no mundo da escrita, a escolarização, as práticas de escrita e o contato com o impresso. Sabe-se, no entanto que, pelo menos até as primeiras décadas do século $\mathrm{XX}$, as taxas de analfabetismo chegavam a quase $70 \%$ da população com mais de 15 anos do país e eram muito baixos os índices de escolarização. ${ }^{1}$ Poder-se-ia supor, então, que, até muito recentemente, somente uma pequena elite cultural brasileira se relacionava com a escrita? ${ }^{2}$

Alguns estudos ${ }^{3}$ têm mostrado que as relações e mediações ocorridas entre indivíduos e grupos sociais e o mundo da cultura escrita são muito mais complexas. Essas pesquisas revelam que grupos tradicionalmente associados à oralidade e que, por muito tempo, encontravam-se dissolvidos em substantivos que, por sua própria carga discursiva, ${ }^{4}$ tendiam a homogeneizá-los - como "povo", "mulheres", "dominados", "excluídos", "negros", "nordestinos" - utilizavam táticas ${ }^{5}$ e, de maneiras particulares (nem sempre coincidentes com as que predominavam em outros grupos sociais "naturalmente" vinculados ao mundo letrado), inseriam-se em práticas de letramento. 
É importante destacar que não estou me referindo a indivíduos excepcionais, mas a homens e mulheres comuns que, muitas vezes pela ausência do registro de suas vidas e de suas trajetórias em documentos oficiais, são remetidos a uma espécie de limbo na pesquisa histórica e educacional.

Os modos de inserção dessas camadas da população no mundo da cultura escrita parecem estar muito mais vinculados a práticas orais de socialização do escrito, à circulação do manuscrito e a modos não-escolares de aprendizagem. Dessa maneira, pode-se considerar anacrônica a perspectiva de abordar os processos de letramento da população brasileira no passado somente a partir da análise da circulação do impresso, da freqüência da população à escola e das práticas de escrita. Então, pode-se perguntar: Por meio de que práticas ocorrem o acesso, o contato e a apropriação ao/do escrito/impresso entre essas camadas? Se a escola não é o principal locus educativo, em que espaços essas práticas se dão? O que caracteriza, especificamente, essa relação dos que estão imersos em um mundo com forte presença da oralidade com a palavra escrita?

Certamente diversas pesquisas podem apresentar respostas a essas questões. Vou tentar discuti-las, no entanto, com base em um caso específico: as experiências de leitura/audição de folhetos ${ }^{6}$ de cordel nas décadas de 30 e 40 do século XX em Pernambuco. Baseio-me, para escrever este artigo, em resultados de uma pesquisa concluída, ${ }^{7}$ que teve como objetivo (re)construir o público leitor/ouvinte e os modos de ler/ouvir literatura de cordel no período e espaço referidos. $\mathrm{Na}$ pesquisa, foram utilizadas como principais fontes entrevistas, autobiografias, romances, os próprios folhetos e outros documentos, como anuários estatísticos, registros censitários e jornais. Os sujeitos entrevistados eram, na época, moradores do Recife e haviam nascido em sua região metropolitana ou em municípios do interior de Pernambuco e da Paraíba, entre 1910 e 1932. Dos nove leitores/ ouvintes que entrevistei, três declararam-se analfabetos, três tiveram experiências de escolarização de até um ano e três passaram de dois a cinco anos na escola. Nas trajetórias de vida de todos eles, os folhetos constituíram o objeto de leitura e/ou audição mais presente.

Em um outro artigo (Galvão, 2001b), que também foi elaborado com base nos resultados da pesquisa, discuto, especificamente, os fatores que parecem ter contribuído para a inserção dos leitores/ouvintes entrevistados no mundo da escrita. A aprendizagem das habilidades básicas de leitura - a alfabetização inicial - seja por processos 
autodidatas, seja por processos de escolarização formal -, constitui o fator preponderante para que os sujeitos se sintam mais habituados ao mundo letrado, fazendo dele parte significativa de suas vidas. No entanto, a partir da aquisição dessas habilidades, o nível de escolarização dos sujeitos não constitui mais, necessariamente, um fator fundamental para as suas experiências de letramento. O nível de inserção dos sujeitos na cultura urbana também se revelou um fator significativo para propiciar uma maior intimidade dos entrevistados com a escrita. Viver na cidade, embora originário da zona rural, imerso em um mundo onde o impresso se encontrava em quase todos os lugares, parecia fundamental, naquele momento, para os processos gradativos de aquisição de uma maior familiaridade com a cultura escrita. Na cidade, destaca-se o papel ocupado pela própria rua, pelos espaços públicos de convivência e, de maneira particular, pelo cinema - extremamente presente no cotidiano da época - que, além de transportar os sujeitos para outros mundos, possibilitava, por meio das legendas, o desenvolvimento das competências de leitura. Além disso, é também a cidade que possibilita aos entrevistados um contato com outros gêneros de escrita além do cordel - igualmente classificados como "subliteratura" -, como os romances policiais, as histórias em quadrinhos e os almanaques.

Também pareceu decisivo para a determinação dos graus de letramento dos entrevistados o seu pertencimento de gênero. As mulheres tiveram contato com uma menor diversidade de objetos escritos e apresentaram menor intimidade com eles. Os diferentes graus de apropriação do espaço urbano estavam diretamente associados ao ser homem ou ser mulher na sociedade da época. Os espaços de sociabilidade femininos eram ainda restritos, mesmo no caso de mulheres pertencentes às camadas populares e engajadas no mercado de trabalho. Finalmente, a ocupação profissional também parecia se constituir em um fator importante para a maior ou menor intimidade das pessoas com a escrita. Sujeitos que exerceram, durante a maior parte da vida, ocupaçôes manuais, assalariadas ou "autônomas" (de subsistência, como o trabalho no campo), ou, no caso da maior parte das mulheres, não trabalharam fora do lar, apresentaram menores níveis de letramento. Trabalhadores em ocupações semi-especializadas, por outro lado, revelaram maior grau de inserção na cultura escrita.

Neste artigo, busco, por outro lado, discutir quais as especificidades da relação que esses sujeitos, os quais, em sua origem, estão, em maior ou menor grau, vinculados a uma cultura em que a oralidade 
é predominante, estabelecem com a cultura escrita. Detenho-me, para isso, no caso do cordel. O que caracteriza essa relação de um sujeito pouco letrado com um objeto escrito e impresso? Essa relação é determinada pelas próprias características desse objeto que, por sua natureza e pela natureza das práticas em que era lido/ouvido, já realiza uma mediação entre o oral e o escrito, entre o memorizado e o compreendido, entre o indivíduo e o outro?

O que caracteriza a aproximação ao mundo da cultura escrita?

\section{$A$ mediação do outro}

Um primeiro ponto que parece caracterizar a relação estabelecida entre o leitor/ouvinte e o cordel é a presença, na maior parte dos casos, nas práticas de leitura, de outros leitores/ouvintes. A leitura dos folhetos, como pude constatar na pesquisa, raramente era solitária. Vários estudos realizados no campo da história da leitura têm mostrado que as próprias situações de leitura determinam a produção de sentidos nos processos de usos e apropriações dos impressos: um mesmo texto, lido em voz alta ou silenciosamente, de maneira intensiva ou extensiva, produz significados diferentes para seus leitores (ver Chartier, 1998).

A primeira instância de leitura/audição de folhetos era, de modo geral, o momento em que as pessoas iam à feira e ouviam o vendedor: leitura competente, declamada ou cantada em voz alta, interrompida no momento do clímax do enredo. Uma vez adquiridos ou tomados de empréstimo, os folhetos eram geralmente lidos em grupo, em reunióes que congregavam grande número de pessoas, na casa de vizinhos e familiares. Aqueles que possuíam um maior número e uma maior diversidade de títulos de folhetos em casa chamavam os parentes e amigos para, coletivamente, desfrutarem das leituras das histórias:

(...) todo mundo sempre tinha um rádio, tinha um baixo-falante em casa

(...) mas o cordel era uma coisa, juntava aquela roda, aquele bocado de gente, a pessoa lia pra divertir várias pessoas e no interior era principalmente que comprava, um comprava aí lia, né? Aí no outro sábado aquele que viu ler aí comprava, tudo comprava, cada qual comprava um, a gente ia pra feira, vendia. (Edson) ${ }^{8}$

Nessa mesma direção, situa-se o depoimento de Zé Mariano. ${ }^{9}$ Nele, não sabemos se a beleza descrita se refere somente às histórias 
ou também, e talvez principalmente, ao ambiente a partir do encontro provocado pela leitura coletiva:

Às vezes os vizinho ia pra lá, aí juntava um bocado de gente assim, sentava um bocado de gente. (...) Os folheto, meu pai tinha aquele bocado de folheto... (...) Aí chegava gente, juntava tudo, ficava na... na... na sala, muita gente, sala grande, aí papai lia o folheto... (...) Era um divertimento (...) Era bonito isso, era bonito, era muito bonito.

Os folhetos também eram lidos ou declamados por grupos menores, nas calçadas - ao lado das conversas cotidianas:

A gente morava num interior chamado... Bem-Te-Vi... (...) ali perto de... Catende, por ali pra dentro. Aí de noite acendia o candeeiro, não tinha nem luz lá no lugar onde a gente morava, interiorzinho pequeno, ele (seu pai adotivo) era delegado lá. Aí eu lia folheto, lia, lia, lia, lia, lia a noite todinha (risos) até 10 horas, 11 horas da noite. (...) Depois, até quando eu me casei lá na Usina Guabiraba, eu saía de noite com o candeeiro, ia pra casa da vizinha assim, de noite, pra ler folheto. (...) Era sentado na calçada e lendo. (Zeli) ${ }^{10}$

Além da leitura dos folhetos, nas reuniōes coletivas, algumas histórias, originárias de folhetos ou não, eram declamadas pelos que as sabiam de memória. Os contadores de histórias divertiam a platéia ao narrar, com habilidade, contos da tradição oral, em especial as "histórias de Trancoso". ${ }^{11}$ Histórias de Antônio Silvino, Lampião e outros cangaceiros, além de histórias de "assombração" e de "safadeza", juntavam-se àquelas que já circulavam na tradição oral e nos folhetos - muitas de valentes e espertalhões -, compondo um tecido formado de fatos e lendas que até hoje são extremamente fortes na memória popular, principalmente nos sertões. $\mathrm{O}$ cenário descrito pelos entrevistados para a audição de histórias é semelhante àquele caracterizado para ler e ouvir os poemas de folhetos. Zeli afirma que seus parentes e vizinhos se sentavam na calçada, geralmente em noites de lua, já que não havia luz elétrica, e cada um contava "a sua história de Trancoso". Crispim ${ }^{12}$ lembra-se de homens e mulheres que passavam toda a noite contando histórias "pra o povo ouvir", principalmente histórias de reis e de princesas: em sua memória, histórias muito bonitas.

Histórias de personagens de folhetos que circulavam, provavelmente há várias gerações, na tradição oral também foram evocadas pelos entrevistados. Zefinha ${ }^{13}$ recorda-se de que ouvia histórias de João Grilo 
decoradas e narradas por sua avó, que as havia aprendido com seu bisavô, fora do suporte do folheto. Para ela, João Grilo é um personagem associado, sobretudo, à tradição de narrar histórias: não conheceu, apesar da popularidade dos poemas, folhetos que narrassem suas proezas. A mesma entrevistada afirma que há muitas outras histórias que não sabe se eram originárias de folhetos ou se circulavam na tradição oral. Não sabe, por exemplo, a origem das histórias que sua avó contava - e poderia saber? ${ }^{14}$ - já que, embora fosse analfabeta e, como tal, uma ouvinte e contadora de histórias, tinha pai alfabetizado e leitor de folhetos. A memória de Zefinha reteve sobretudo se eram histórias rimadas ou não: seu depoimento ilustra a circularidade com que certos temas e enredos passam do oral ao escrito, do escrito ao oral, do popular ao erudito, do erudito ao popular. Neste trecho da entrevista, revela sua percepção acerca dos processos de transmissão dessas histórias ao longo das gerações:

Tinha história que não era rimada. Minha avó, por exemplo, nossa senhora, ela contava cada história, é porque que eu nunca decorei... (...) E... tinha história que eu nem sei nem se era de folheto. Eu sei que a vida desse pessoal é assim, né? Que eles... parece que eles... vêm de geração em geração... Aí um conta uma história, o outro decora, aí vai passando de pai pra filho, pra neto, e pra bisneto, né? (...) Tinha muitas histórias que ela contava que ela dizia que era o meu bisavô, o pai dela, que contava, né? (...) Porque ela aprendia com meu bisavô, que era o pai dela, e ele sabia ler, né? E ele tinha muito folheto... Aí cont... lia todas as noites pros filhos, quando eram solteiros tudinho em casa, né? - e aí cada um que decorava a história.

Nas memórias e nos romances analisados, também se observa a pregnância de certas histórias e de certos temas que circulavam na memória coletiva e se manifestavam em autos populares, em folhetos, em livros em prosa, em contos tradicionais, como, por exemplo, encontram-se referências às batalhas entre cristãos e mouros infiéis, à coragem dos Doze Pares de França, às espertezas de Pedro Malasarte, personagens bastante populares na tradição oral e no universo da literatura de folhetos.

À semelhança do que ocorria com o leitor de folhetos, que deveria demonstrar competência para ler ou declamar os poemas, os entrevistados também se referiram à necessária habilidade do contador para narrar as histórias diante de uma audiência. Para Ana Maria, ${ }^{15}$ o narrador, para que as histórias se tornassem realmente "bonitas", tinha que dar "cadência" aos enredos. 
Também de maneira semelhante ao que ocorria com a leitura de folhetos, as histórias narradas não precisavam ser inéditas para que os auditores sentissem prazer em ouvi-las: podiam ser as mesmas por dias seguidos. Caso alguém soubesse de outras, para variar o repertório, eram bem-vindas. Para a audiência, no entanto, como já foi mostrado em diversos estudos, parecia ser mais importante a performance do narrador, a reiteração de valores universais rememorados a cada nova narração, do que propriamente o enredo ou o final da história.

$\mathrm{Na}$ memória de muitos entrevistados, a leitura coletiva dos folhetos estava estritamente relacionada também a uma tradição encontrada em diversos países, mas que assume uma face peculiar principalmente nos sertôes brasileiros: as cantorias, que ocorrem no Nordeste desde meados do século XIX (Cascudo, 1984). Para aqueles que viveram a maior parte da vida nas pequenas cidades do interior do estado, as principais diversões de que desfrutavam eram, além da leitura e da audição de folhetos, os cantadores: "A gente andava duas léguas de noite pra o... pra ouvir os cantadores cantar. (...) Era um espetáculo na época" (Zeli). As cantorias geralmente se davam nos engenhos ou nas fazendas e os repentistas eram contratados pelos proprietários das terras. A ocasião era uma grande festa:

Oxente, eu andava uma légua de noite para ir assistir. (...) Naquelas casas de engenho, né? O senhor de engenho, por ali. A gente ia, mandavam avisar que à noite tinha umas cantoria lá. Quando é de noite ia a gente mais o inspetor, que era so... que aquele homem que ajudava a polícia chamava inspetor, né? (...) Ia o inspetor, o ajudante do inspetor, ia tudinho. (...) Chegava lá, a gente ia ver os cantador cantar, tinha cachaça pra beber, tinha café, tinha pão, bolacha... Até meia-noite terminar, a gente vinha tudo pra casa. (Zeli)

As cantorias ocorriam também nas feiras, onde violeiros, emboladores com pandeiros e tocadores de rabeca divertiam a audiência que em torno deles se aglutinava.

Em suas narrações, Antônio ${ }^{16}$ destaca as características valorizadas naqueles considerados bons cantadores, "verdadeiros artistas", segundo o entrevistado: a perspicácia, a capacidade de improvisação - de compor versos sobre aquilo que não sabe -, a percepção da fragilidade do outro, a persistência em manter o desafio até que o oponente se canse e desista, o humor e a capacidade de, por meio da ironia e da esperteza, desafiar e superar o outro, característica de alguns cantadores. Em conseqüência do estreito controle exercido 
pelo outro cantador e pela audiência na produção dos desafios, era necessário que houvesse um minucioso processo de preparação para enfrentar a situação. Nesse processo, segundo Antônio, os cantadores liam sobretudo "livros históricos do passado":

(...) porque só em você saber que o repentista não canta o que ele sabe, não. Ele canta o que você pede pra ele cantar. (...) Você lê uma história, vamos supor, "Os Doze Pares de França" (...) "Carlos Magno"... "O Reino de Alexandria", "Luiz de Borgonha"... Entendeu? Aí você diz assim: "Não, é a história de Ferrabrás". Não foi nem dos três, de Ferrabrás que era um guerreiro contra... Oliveiros. (...) Entendeu a história? (...) Se eu perguntar, "Ô...”, naquela época: "Fulano, dá pra você se conter sobre 'Oliveiro e Ferrabrás"”? Ele vai do começo até o fim (enfático). (...) "Oliveiro e Ferrabrás”, mas ele sabe, ele leu aquilo tudo lá...

Como se pode observar, o fato de os folhetos serem lidos predominantemente de maneira coletiva e estarem, direta ou indiretamente, inseridos em uma rede de tradição oral - representada pelos contos populares e pelas cantorias - tornava-os mais próximos daqueles que apresentavam pouca intimidade com o mundo da escrita. Esses leitores/ouvintes, mesmo quando eram analfabetos, pareciam se sentir mais à vontade em um mundo já marcado pela presença da escrita, pelo fato de poderem dela partilhar por intermédio de instâncias coletivas de sociabilidade.

\section{A oralidade}

Além de coletiva, ou seja, mediada por outras pessoas, a leitura de folhetos era, também, oralizada. O fato de ser realizada em voz alta também parecia constituir em um fator decisivo para que, mesmo os analfabetos, vivenciassem práticas de letramento e, em alguns casos, até aprendessem a ler.

Como se dava, então, essa oralização da leitura? Como se viu, os parentes e vizinhos constituíam a audiência privilegiada para ler/ouvir folhetos. Todos os entrevistados revelaram que era corrente a presença de pessoas analfabetas no grupo de ouvintes. Em muitos casos, mesmo sem saber ler, compravam os folhetos e pediam a outra pessoa que os lesse em voz alta. Os analfabetos, assim, "acompanhavam" os enredos das histórias dos poemas. ${ }^{17}$

$\mathrm{Na}$ maior parte dos casos, os membros mais alfabetizados e com competências de leitura consideradas satisfatórias pelo grupo, 
liam as histórias em voz alta para os demais. ${ }^{18}$ Para os entrevistados, à semelhança do que deveria ocorrer com o vendedor, era fundamental que o leitor tivesse fluência, tom de voz e entonação adequados para que a audiência pudesse fruir adequadamente da estética dos poemas: era preciso que soubesse manter o ritmo e destacar bem algumas frases. Assim, além de a história ser "bonita", seu leitor deveria ter habilidades específicas para que os demais desfrutassem de sua leitura da maneira mais prazerosa possível.

No entanto, em alguns casos, o fato de o leitor não possuir todas as competências de leitura parecia não diminuir o prazer dos ouvintes: "Minha mulher sabia muito ler, aí ela lia pra tudinho. (...) Era um divertimento. Ela lia assoletrando mesmo, faltando as letra" (Zé Mariano). Cena com elementos semelhantes é descrita por Edson: o membro mais alfabetizado, embora nem sempre um "bom" leitor, depois de um dia de trabalho na agricultura, no início da noite, sob a luz do candeeiro, lia poemas de folhetos, em voz alta, para os demais:

Então era muito bom, aqueles agricultores que trabalhava na enxada o dia todinho, de tardezinha pegava o candeeiro, botava assim, aquele mais, aquele mais... desarnadozinho, né? Lia, gaguejando de todo jeito, o pessoal ria à vontade até... dez, onze horas pra dormir. Dez horas, nove horas, o pessoal ia dormir.

Em muitos casos, os membros mais alfabetizados da casa eram as crianças, em geral com um grau de escolarização maior que o dos pais. Essa foi a experiência de Zé Mariano, de Crispim, de Ana Maria e de Delita ${ }^{19}$ com seus filhos; e de Zeli e Zezé, ${ }^{20}$ elas mesmas meninas leitoras de folhetos. O depoimento de Crispim é interessante para perceber o papel dos meninos e das meninas nos momentos coletivos de leitura de folhetos: pareciam funcionar como mediadores entre a cultura escrita, na qual pouco a pouco se inseriam, e a cultura oral, na qual estavam imersos seus pais, os quais, por meio deles, memorizavam a palavra impressa:

Eu... eu sei que meu cunhado, olhe os filho dele aprenderam a ler lá no... no... numa escolinha que tinha lá perto de casa. E depois já tudo formado, rapaz e mocinha comprava... comprava folheto e lia em casa, né? Era os filho lendo e ele decorando. Quando a gente ia pra rua que voltava lá pra casa e juntava uma porção de gente...

Muitos estudos realizados sobre literatura de cordel no Brasil apontam o papel dos folhetos na alfabetização de um significativo 
número de pessoas, principalmente na época de seu apogeu. ${ }^{21}$ Entre as pessoas que entrevistei, a maioria conhecia alguém ou tinha ouvido falar sobre a aprendizagem inicial da leitura por meio dos folhetos:

Mesmo quem não sabia ler comprava e aprendia a ler lendo cordel, decorava. E terminava aprendendo a ler (risos) por causa do cordel, né? Porque decorava aquela leitura do cordel (...) Ouvia e decorava e depois ia pra feira e daqui a pouco tava lendo folheto... (...) Acabava aprendendo, porque ele via o pessoal sempre com inveja, aqueles... lê aquilo ali, eles decorava, né? Então dali ia juntando as letra, daqui a pouco sabia ler. (...) Acompanhando. O cordel é uma coisa da antiguidade que... trouxe a muita gente aprender a ler que comprava o folheto, porque queria ler também e terminava lendo. (...) Eu conheço, aqui não, no interior, né? Muita gente que aprendeu a ler por causa do cordel. (Edson)

$\mathrm{Na}$ mesma direção, Zeli associa a aprendizagem da leitura à audição dos folhetos: "Via, ouvia, gostava e pegava e ia ler, soletrando e aprendia (...) muita gente aprendeu a ler com o folheto". Relaciona esse papel da leitura dos folhetos diretamente ao que parecia ser sua função ou sua conseqüência primeira: o lazer, o divertimento, a inserção em um mundo mágico. $\mathrm{O}$ interesse despertado pelas histórias - a dimensão estética das obras é destacada - é que determinava essa função de cunho mais pragmático da leitura: "Era, ia aprendendo, era. Com o folheto ia aprendendo a ler. Interessava-se pela história, né? E ia aprendendo a ler, ia assoletrando, né? (...) Era umas histórias bonitas de rei e rainha, das fadas (...)? Tinha... era umas histórias... cada história bonita...”.

Os depoimentos parecem indicar, assim, que a alfabetização das pessoas por intermédio do cordel se dava de maneira autodidata: por meio da memorização dos poemas, lidos ou recitados por outras pessoas, o "alfabetizando", em um processo solitário de reconhecimento das palavras e dos versos, dava, ele mesmo, um significado a esse novo sistema: a escrita. ${ }^{22}$ Aos poucos, esse processo se ia estendendo a outros objetos de leitura.

A maioria dos entrevistados destacou a leitura de folhetos como fundamental para desenvolver as competências de leitura. Diante da minha questão sobre pessoas que aprenderam a ler por meio dos folhetos, Zé Moreno não hesitou em se colocar como um caso exemplar, embora, no conjunto de seu discurso, tenha atribuído, sobretudo ao cinema, o desenvolvimento de suas capacidades de leitura. No trecho abaixo, da entrevista, o entrevistado destaca 
novamente a dimensão estética - materializada na rima - como fundamental na leitura de folhetos, mesmo quando ela servia, principalmente, para desenvolver as competências de leitura. Nesse momento, compara o prazer desfrutado na leitura de folhetos com o enfado provocado pelas lições escolares, conhecidas em sua curta experiência de escolarização:

Ah... Matuto não passa muito tempo na escola. Passa mais na porta da escola. Aprendi pouco. Eu vi só a carta de ABC e talvez nem toda. (...) Eu... foi quem me desenvolveu. Porque eu aprendi na escola... a carta de ABC num versa, versa? É só aqueles dizerzinhos (como se estivesse recitando:) “é meu pai, eu vou ler (...) vou ler mais" (voltando a falar normalmente), essas coisinhas, né? Dali aprendi, aprendi a juntar as duas sílabas, as duas letras pra fazer a sílaba, depois nome, pronome, não sei o quê, não sei o quê, não sei o quê, e fui juntando e o cinema me imprensou mais, me ajudava a desenvolver. (...) E foi isso minha vida. Eu aprendi ler quase no folheto. $\mathrm{O}$ folheto foi meu professor. (...) $\mathrm{Na}$ escola só fazia aprender bobagem.

Zé Mariano, que nunca aprendeu a ler, tem uma história particularmente interessante. Filho de pai alfabetizado, de quem ouvia as leituras de folhetos quando era menino, ainda no interior da Paraíba, depois de adulto, continuou a ouvir folhetos, dessa vez com o auxílio da mulher e do filho, também alfabetizados. $\mathrm{O}$ entrevistado destaca o papel dos folhetos para desenvolver as capacidades de leitura:

Ele gostava de ler (seu pai) por causa de... ele (...) gostava de ler, ele decorava o folheto pra... pra... pra miorar a leitura. (...) Pra miorar a leitura, sabe? Aí meu pai, meu pai gostava de usar muito folheto. Dava aos meninos e dava pra dar a gente, né? Quem sabesse ler, pra decorar a leitura, pra desarnar a leitura, sabe? (...) Ele sabendo ler o folheto ele... ele pode... pode dizer de cor, pode dizer as coisa de cor.

Zé Mariano repete o procedimento que seu pai fazia com ele próprio, em relação a seu filho:

De lá pra cá eu comprei pro meu menino, meu menino tava acanhado, num sabia soletrar uma letra, aí eu comprei pra ele os folheto, pra ele... pra ele saber, pra instruir, pra ele aprender, desarnar as letra e tudo. (...) Aí eu... eu entreguei a ele, comprei o folheto pra ele, aí ele pegou, de... de... desarnou a letra. Isso aí melhorou mais a leitura dele. (...) Isso tudo é bom pra o menino que tá aprendendo ler, quando num sabe ler. Pra ver o menino (...), num sabe soletrar a letra, num sabe juntar uma letra, aí... o fo- 
lheto explica, né? Ele lê aquele folheto, o folheto explica. Aí sai, sai, sai, aí vai... alguém vai desarnando.

Desse modo, pode-se perceber que o fato de serem lidos em voz alta parecia constituir um fator decisivo para que os folhetos contribuíssem efetivamente para a inserção de pessoas, imersas em uma cultura fortemente marcada pela oralidade, mediadas por um membro do grupo que possuía maior intimidade com a escrita, no mundo letrado.

\section{A memorização}

Além de mediada pelo outro e pela oralidade, a leitura de folhetos também se caracterizava por um outro componente diretamente relacionado aos dois anteriores - que parecia decisivo para torná-la mais próxima daqueles que não tinham muita intimidade com o mundo da cultura escrita: a memorização. Quase todos os entrevistados - exceção feita a Zé Mariano - sabiam trechos de cor de pelo menos uma história. Os depoimentos revelaram, ainda, que, em muitos casos, as pessoas, quando iam comprar alguns folhetos, já sabiam as histórias de memória. A compra do livreto parecia se constituir na possibilidade de apropriação definitiva, concreta, por meio da posse de um objeto material, da história, já previamente apropriada pela memorização.

A memorização, na percepção dos entrevistados, estava diretamente relacionada à própria compreensão dos poemas. Parecia se constituir, desse modo, em uma verdadeira apropriação da leitura: os depoimentos revelam que, mesmo quando se lembram de partes do enredo das narrativas, os entrevistados só consideram que "sabem" das histórias quando as retêm na memória, em um processo semelhante ao que ocorre nas sociedades orais ou com fortes resíduos de oralidade. De modo semelhante a Eric Havelock (1988, 1995), para Walter Ong (1982), o fato de, em uma cultura oral, as palavras estarem restritas ao som não determina apenas os modos de expressálas, mas também os processos de pensamento e de estocagem do conhecimento: "You know what you can recall" (p. 33).

No grupo de sujeitos que entrevistei, foram os alfabetizados e com maior grau de intimidade com o mundo letrado que revelaram possuir maior capacidade de memorização. Talvez o fato de o folheto ser uma forma de poesia necessariamente e, antes de tudo, escrita e 
impressa, mesmo possuindo muitas características da oralidade, ajude a explicar esse dado. Zé Mariano, analfabeto e revelando-se incapaz de memorizar qualquer história, atribui a capacidade de memorização a habilidades individuais de cada sujeito: "Acho que decorava de cor porque às vezes tinha gente que tinha bom entendimento na cabeça, tinha aquele entendimento bom, aquele senso bom na cabeça, aí pegava aquelas... aquelas palavras e lia, dizia de cor”. Crispim, também analfabeto, um pouco constrangido no início da entrevista, afirmou que poderia dar-me o nome de alguns poetas/"cantores" de que se lembrasse; no entanto reiterava sua incapacidade de decorar os versos. Em seu depoimento, é interessante observar como simboliza e representa um mundo para ele desconhecido - o da palavra escrita: "Agora o que eu só posso dar pra senhora o nome dos... dos cantor, os que eu me lembrar... mas aqueles que eu não me lembrar eu não posso lhe dar eles. E nos segmentos da letra eu não posso dar, porque eu não decorei nada (enfático)" (grifos meus).

No entanto, analfabetos também eram capazes de memorizar e declamar as histórias, como já demonstraram diversos estudos que se detêm sobre as relações entre oralidade e letramento. Zefinha, por exemplo, mostrava-se impressionada com a capacidade de sua avó de, mesmo analfabeta, memorizar poemas que duravam cerca de "meia hora". ${ }^{23}$

Como já foi referido, alguns entrevistados declamaram, de memória, alguns poemas. Comparei as recitaçôes orais realizadas por Zé Moreno e por Antônio com o texto de A chegada de Lampião no inferno, de José Pacheco. Era uma história extremamente popular na época e uma das preferidas para ser memorizada. O próprio poema apresenta várias características, como a recorrência a expressóes típicas de um dialeto oral regional, que o tornam muito próximo à oralidade. Além disso, o ritmo das estrofes é muito rápido, parecendo favorecer a memorização. A história toda tem um tom irônico, jocoso; com esse tom, os entrevistados recitaram-na.

Acredito que algumas considerações podem ser feitas com base na análise realizada. Em primeiro lugar, pela própria entonação da declamação dos entrevistados, mesmo para um auditor pouco habituado ao universo do cordel, é possível identificar quando se inicia e quando se encerra cada um dos versos e cada uma das estrofes. A comparação entre a recitação e o poema escrito revela a existência de pequenas alteraçóes feitas pelos entrevistados. Essas alterações, no entanto, não eliminam a rima, o ritmo e o próprio conteúdo semântico 
básico de cada estrofe. Em alguns casos, os sujeitos invertem um ou outro verso, substituem palavras por sinônimos, o que não compromete nem a idéia do poeta, nem a rima, nem o ritmo. Em outros casos, os entrevistados interromperam as declamações, retomando-as após alguns minutos e depois de tecer alguns comentários sobre o enredo do poema, o que mostra, por um lado, a consciência de que não estavam recitando os versos exatamente como na versão escrita e, por outro, a compreensão do enredo, da narrativa propriamente dita.

As alterações observadas entre o que Zé Moreno e Antônio retinham de memória e as edições do folheto são, portanto, relativamente pequenas, principalmente quando são consideradas as dimensões dos poemas: relativamente extensos principalmente para quem não está imerso em culturas com fortes marcas da oralidade, nem tem o hábito de memorizar. ${ }^{24} \mathrm{O}$ esquecimento de algumas estrofes - secundárias no conjunto dos poemas - pode ser explicado, inicialmente, como os próprios entrevistados afirmaram, pela distância temporal que separa os contextos originais de declamação - quando praticavam com freqüência esse exercício - e a situação provocada pela entrevista. Além disso, a declamação realizada por ocasião da entrevista pode ser considerada artificial, fora do contexto real em que a prática se dava, e a audiência, que assume um papel fundamental na performance do declamador, restringia-se a uma única pessoa, pesquisadora interessada em um objeto em "extinção".

Finalmente, o que se pode observar, com base na análise comparativa realizada entre os textos dos folhetos e os poemas recitados e mesmo com base no que registram memórias e romances sobre questōes semelhantes, é que, como já mostraram diversos estudos, cada performance na poesia oral - ou, nesse caso, oralizada - ocorre entre a repetição e a criação. Entre a fala e o gesto, o que o poeta viu e ouviu e a rememoração e o improviso, realiza-se a performance oral (Machado, 1995). Desse modo, ao mesmo tempo que está inextricavelmente fundida à tradição, a literatura oral revela-se única, irrepetível. Albert Lord (1960), em estudo clássico, ao analisar a performance de cantores, verificou que aquilo que era considerado tradicionalmente como o mesmo poema nunca se repetia da mesma forma. Cada apresentação se constituía em uma nova composição, em um processo dinâmico de criação e, ao mesmo tempo, de conservação. Nos processos de produção da literatura oral, a recepção assume, pois, um papel fundamental. O poeta, ao apresentar-se para uma audiência variada, pode controlar sua produção em função dos interlocutores. 
Mas o que possibilitava essa memorização? Afinal, muitos folhetos eram longos - variavam, em média, de 8 a 64 páginas. Dois fatores parecem se destacar: o primeiro é que as leituras eram realizadas de maneira intensiva. $\mathrm{O}$ segundo refere-se às características formais e ao próprio conteúdo dos poemas.

Como já referido, os folhetos pareciam ser lidos sobretudo de uma maneira intensiva. ${ }^{25}$ Os mesmos poemas eram retomados diversas vezes pelo mesmo leitor ou pela mesma audiência. $\mathrm{O}$ depoimento dos entrevistados parece revelar que o interesse na leitura e na audição dos folhetos residia não exatamente na expectativa de resolução dos conflitos apresentados pelo autor, no desvelamento do enredo/história em si ou na notícia e em seu desfecho, mas na possibilidade de rememoração e na contínua apropriação de conceitos, práticas, idéias gerais e universais, não referidos a um contexto imediato, presentes nas histórias. Os entrevistados voltam, assim, aos mesmos folhetos, mesmo quando eles são noticiosos. A atualidade da notícia parece não ser uma categoria importante: os poemas não são considerados descartáveis, na medida em que, de alguma forma, reiteram valores e atingem a sensibilidade do público leitor.

A leitura da mesma história várias vezes possibilitava a sua memorização: "Eu lia tanto que sabia todo já decorado" (Zeli). Zé Moreno afirma: "Lia uma vez, duas, três, na quarta já ia, corrigia (...)". A rima e o ritmo da poesia pareciam fundamentais nesse processo. Edson, por exemplo, afirma que as histórias tradicionais publicadas em forma de livro, em português ou mesmo em espanhol, deixaram, gradativamente, de ser lidas, na medida em que os folhetos rimados se foram popularizando: “(...) o livro (...) desapareceu logo, depois que apareceu o rimado, o livro, os espanhóis, os portugueses deixaram de vender porque ninguém queria. Só queriam os livros rimados porque era mais engraçado, era um livro mais... que entendiam melhor, né? (...). Livro em prosa é mesmo que tá lendo um livro de leitura, um livro de..., um livro didático, né?". Edson esclarece, ainda, que os folhetos eram mais fáceis de ser entendidos e memorizados, o que não acontecia com os livros em prosa de modo geral: "É mais difícil entender o que tem escrito no romance, no romance de bolso, livrinho de bolso. E o folheto não, a pessoa lia, achava graça (...), até decorava”.

A própria estrutura formal dos poemas, portanto, facilitava a sua memorização. Antônio afirma que decorava de quatro a seis versos de cada vez. Parece, assim, que o agrupamento de estrofes, em geral 
compostas em um mesmo padrão métrico, facilitava a memorização dos poemas por parte de seus leitores e ouvintes. $\mathrm{O}$ mesmo entrevistado acrescenta outro dado interessante: segundo ele "lendo quatro, cinco livros você grava". Assim, parece que a introjeção das fórmulas básicas, típicas da composição dos cordéis, auxiliava na memorização de qualquer poema: os leitores e os ouvintes habituados ao universo dos livretos apresentavam poucas dificuldades para, entrando em contato com uma "nova" história, reproduzi-la de memória. As narrativas orais obedecem, como têm demonstrado estudos que se detêm sobre as relaçôes entre oralidade e letramento, a certos padrões de composição que auxiliam na performance dos poetas, na memorização e na incorporação de temas e valores por parte da audiência. O esquema narrativo é, na maior parte das vezes, mais importante que os detalhes do conteúdo das narrativas. As fórmulas - grupo de palavras nas mesmas condições métricas e que obedecem a um mesmo padrão sintático -, o ritmo e a estabilidade de certos temas e idéias facilitam a tarefa do poeta e auxiliam a audiência na memorização. Os autores que estudam a literatura de cordel brasileira também encontram, em sua estrutura, a recorrência a certas fórmulas e padrões de composição, semelhantes aos encontrados nas narrativas orais:

Uma das características formais da Literatura de Cordel é a obediência a modelos de composição, dos quais o poeta popular procura não fugir.

Há sempre repetições do mesmo tipo de estrofe e dos padrões métricos e contínua retomada dos mesmos assuntos, o que assegura à Literatura de Cordel uma perenidade, formal e de conteúdo, decorrente da exploração reiterativa dos mesmos topoi estilísticos e temáticos. Quanto mais o folheto se amolda aos procedimentos tradicionais, mais aplaudido e apreciado se torna. (Tavares Júnior, 1980, p. 60)

Repetição e renovação. Entre esses dois movimentos, o poeta cria seus versos. Ivan Proença (1977) afirma que o poeta será “... tanto mais importante quanto menos original se mostra, isto é, quando mais seguir as fórmulas e os usos tradicionais. Daí provavelmente, o emprego intensivo de variado material clichê, lugares-comuns, chavôes" (Proença, 1977, p. 42).

Desse modo, a própria estrutura dos poemas parecia facilitar a memorização. $\mathrm{Na}$ pesquisa, analisei mais detidamente o texto dos poemas de oito folhetos (de um conjunto de 107), publicados entre as décadas de 1930 e $1940^{26}$ e citados por mais de um entrevistado, buscando reconstituir o "caminho" percorrido pelo poeta para cons- 
truir sua narrativa: que expectativas gera no leitor, que antecipações prevê, que elementos retoma ao longo do texto etc. Busquei examinar esses aspectos principalmente por meio da análise das capas, dos momentos em que o poeta se dirige diretamente ao leitor e da primeira e da última estrofes do poema. Além disso, busquei detectar marcas da oralidade e as indicaçôes, nos textos, sobre a "enciclopédia" do leitor (Eco, 1986) esperada pelo autor e/ou editor e levantar hipóteses acerca do tipo de raciocínio ou operação exigidos do leitor para que ele pudesse fazer uma leitura fluente, sem maiores dificuldades. De modo geral, as capas, os títulos e o número de páginas dos poemas, conjuntamente, já geram no leitor uma série de expectativas que o fazem antecipar alguns elementos da história que será narrada e em que subgênero (romance, "de acontecido" etc.) se insere no universo do cordel. Em todos os folhetos analisados, as primeiras estrofes parecem cumprir o papel de apresentar os principais elementos do poema. Por meio delas, o leitor conhece os protagonistas da história, em geral julgados de maneira positiva ou negativa pelo poeta, que utiliza adjetivos para fazer essa classificação, induzindo o leitor a se situar do lado do bem ou do mal, e é introduzido no universo específico daquele subgênero de folhetos. As estrofes seguintes, de certa forma, constituem o desdobramento da primeira estrofe: nelas são apresentados os personagens, servem como uma introdução dos elementos principais da história e funcionam para antecipar certas expectativas do leitor.

De modo geral, sempre que introduz um novo personagem, um novo fato ou até mesmo um novo cenário que desempenhará um papel importante na narrativa, o poeta interrompe-a, chamando a atenção do leitor para a importância do que vai narrar. $O$ poeta também chama a atenção do leitor quando volta a um assunto sobre o qual já escreveu anteriormente, em um procedimento bastante semelhante ao utilizado nas narrativas orais. Segundo Ong (1982), a repetição do "já-dito" pelo falante atende a certas expectativas do ouvinte em relação aos mesmos temas e às mesmas formas. Para o autor, a eliminação da redundância demanda uma tecnologia que implique na utilização de um espaço de tempo maior: a escrita. Com ela, a mente é forçada a tornar o pensamento mais lento, oportunizando a reorganização da linguagem, eliminando as repetições desnecessárias.

Em um procedimento também típico da oralidade, em $A$ batalha de Oliveiros com Ferrabraz, nas estrofes 65 a 67, o poeta interrompe a narrativa e dirige-se diretamente ao leitor. Parece se esquecer de que tinha que narrar outra parte da história contida no livro de Carlos 
Magno. Sem se utilizar de um procedimento básico da escrita - refazer o texto antes de torná-lo público, incorporando o episódio ao poema sem explicitar seu esquecimento -, conta ao leitor, como se estivesse conversando com ele, a sua falha. Essa estrofe também parece revelar, a julgar pelo verso "Quem sabe há de se lembrar", que, pelo menos parte do público leitor suposto pelo poeta, era formado por pessoas familiarizadas com a história:

\author{
Eu agora me lembrei \\ da falta que cometi, \\ mas foi porque me esqueci \\ por isso não relatei \\ porém sempre falarei \\ para o leitor se agradar \\ quem sabe há de se lembrar \\ na luta dos cavaleiros \\ o cavalo de Oliveiros \\ quando quis desembestar. \\ (A batalha de Oliveiros com Ferrabraz, p. 21, grifos meus)
}

Em três poemas analisados, História da princesa da Pedra Fina, $O$ pavão misterioso e As proezas de João Grilo, o poeta recorre a um esquema narrativo bastante previsível. Nesses folhetos, vários episódios semelhantes, em geral colocando os protagonistas em situaçôes de obstáculos ou de desafios, repetem-se. É assim que o herói José, com a ajuda da princesa, enfrenta os obstáculos propostos pelo rei e o barbeiro, em três momentos diferentes, em História da princesa da Pedra Fina. Evangelista e Crêuza superam os obstáculos impostos pelo conde - em quatro episódios - para permanecerem juntos, em $\mathrm{O}$ pavão misterioso, e João Grilo mostra sua esperteza e sua astúcia, em várias pequenas narrativas muito semelhantes entre si, enganando os fortes e poderosos. As estrofes finais dos poemas analisados trazem, de modo geral, o desfecho da história, acompanhado, em muitos casos, de um julgamento dos personagens ou de uma "lição" ou mensagem de cunho mais universal.

Mas, além de trazerem características que os assemelham às narrativas orais no próprio caminho narrativo utilizado pelo poeta na elaboração do poema, como outras marcas da oralidade estão presentes em sua composição? Como mostram os estudos sobre História da Leitura, esses "índices de oralidade" 27 não se constituem 
em representações de práticas de oralidade, mas se referem aos dispositivos depositados nos textos, explícitos ou implícitos, que conferem a eles uma destinação oral (Chartier, 1998). Em todos os folhetos analisados, verifiquei a utilização de um léxico, de expressões e de uma sintaxe típicos do dialeto regional oral. A pontuação utilizada parece, muitas vezes, obedecer mais ao ritmo da fala, declamatória ou não, do que às exigências da leitura. Em As proezas de João Grilo e A chegada de Lampião no inferno, esse aspecto é facilmente observável, o que parece ser um indício de que os poemas eram para ser lidos em voz alta e/ou por alguém ainda muito imerso no mundo da oralidade - um leitor "precário", "inseguro", "inicial”. Para o leitor "seguro", "antigo", torna-se até mesmo difícil a leitura com esse tipo de pontuação:

\section{João disse só tem garapa}

Disse o padre, de que é?

João Grilo respondeu logo

É do Engenho Catolé

Disse o padre pois eu quero

João levou na coité. (As proezas de João Grilo, grifos meus)

Um outro ponto analisado nos textos, com o objetivo de compreender a força de marcas da oralidade neles presentes, refere-se à utilização do discurso direto, dos diálogos, na construção dos poemas. Constatei que o discurso direto é essencial na elaboração dos folhetos; em quase todos eles, desempenham um papel nuclear na condução da narrativa, o que leva a aproximar, mais uma vez, os folhetos das narrativas orais.

É comum, na literatura especializada, a referência à importância dos adjetivos e dos epítetos na elaboração das narrativas orais. Segundo Ong (1982), o modo de pensar oral seria mais agregativo do que analítico. Essa característica é expressa, por exemplo, na grande carga de epítetos e outras fórmulas que caracterizam a expressão oral e que são rejeitadas pela "alta" literatura, por provocarem, em sua avaliação, redundância e monotonia na linguagem. Busquei, com base nessa constatação feita em outros estudos, observar a importância deles, no grupo de folhetos analisados, na condução da história e na produção de certos impactos possíveis em sua recepção. Por meio da simples listagem dos adjetivos utilizados pelo poeta ao longo dos poemas, é possível realizar certas suposiçōes a respeito dos personagens e da história propriamente dita e 
reconstruir, em linhas gerais, o próprio enredo, a partir das mudanças observadas na caracterização dos personagens. Somente esse fato expressa a importância do papel que assumem na elaboração dos poemas. Os protagonistas das histórias, possivelmente por serem mais referenciados, mas também por desempenharem papel nuclear nas histórias e cumprirem um papel, junto ao leitor, de norteadores daquilo que será o "bem" e o "mal" no enredo, são os mais adjetivados. Na maioria dos casos, o uso expressivo dos adjetivos na construção dos poemas parece querer deixar claro para o leitor de que lado se situam os personagens. Cumprem, pois, o papel de localizador das forças do "bem" e das forças do "mal", do herói e do inimigo, deixando pouca margem para ambigüidades. $\mathrm{O}$ poeta parece pressupor, pois, a existência de um leitor com pouca capacidade de complexificação dos personagens e do enredo. Muitas vezes, os adjetivos utilizados são extremamente fortes e, em alguns casos, hiperbólicos. No entanto, há casos de folhetos em que a ação dos personagens ao longo do texto é mais importante que a sua qualificação prévia. Nos romances, o papel demarcador dos adjetivos ocorre com mais força, talvez por cumprirem, neles, um papel mais importante que nos outros tipos de história; são, além disso, histórias mais longas, exigindo uma concentração maior do leitor. O processo de adjetivação dos personagens, das ações e dos fatos parece dar, ainda, à narrativa, um tom dramático, o que certamente contribui para causar, no leitor, um grande impacto emocional.

Em todos os folhetos analisados, em diferentes graus e de maneiras diversas, o elemento mítico-religioso, expresso por meio de ações sobrenaturais (os processos de encantamento e desencantamento, a magia), da força inevitável do destino (da sina, do acaso), da religiosidade cristã, da presença da morte, está presente. O elemento sobrenatural é, na verdade, constitutivo das narrativas orais tradicionais e do imaginário popular, de forma geral. A ação de forças sobrenaturais, em geral auxiliando o herói na superação dos obstáculos que lhe são impostos e, portanto, no cumprimento de seu destino, está bastante presente nas histórias de folhetos. Mesmo quando o poema não traz elementos sobrenaturais, a presença do destino ou da sina - assim como da religiosidade cristã - é extremamente importante na argumentação do poeta para explicar a ocorrência de determinados fatos. Além disso, em quase todos os poemas analisados, a morte é algo essencial na própria construção das histórias.

Além de trazer marcas da oralidade em sua estrutura narrativa, no léxico, na sintaxe utilizados, os textos, mesmo quando se referem 
a locais imaginários e a um mundo relativamente abstrato, sem aparente relação com o cotidiano do suposto leitor, trazem em seu núcleo elementos universais, como a questão do antagonismo entre o bem e o mal e valores como a valentia, a coragem, a persistência, a fidelidade, a obediência, que contribuem para aproximá-los de quem lia. A análise parece mostrar, assim, que os poetas introduziam, em seus poemas, elementos extremamente cotidianos e circunstanciados, próximos da vida diária do suposto leitor/ouvinte e, ao mesmo tempo, aspectos aparentemente estranhos ao mundo em que estava inserido - como personagens mitológicos, reinos, príncipes e princesas -, mas que podem ser caracterizados como universais, na medida em que trazem uma grande carga de idéias e valores que não se vinculam, necessariamente, a um tempo, a um espaço e a uma cultura determinados.

\section{Considerações finais}

Pode-se considerar, com base nas discussōes realizadas, que vários fatores contribuíam para que as relaçōes entre analfabetos e semi-alfabetizados e a leitura de folhetos fossem marcadas pelo prazer, pela tranqüilidade, por um relativo desprendimento - e não pela tensão, pela insegurança, pela incerteza -, como parecia ocorrer em outras situações em que a presença do escrito era predominante e como é comum ocorrer entre os "novos leitores". Essas práticas permitiam, a pessoas que, em sua origem, estavam pouco habituadas ao mundo da escrita, vivenciarem práticas de letramento, ou seja, experimentarem situações em que utilizavam, efetivamente, as palavras escrita e impressa.

Um primeiro fator parece estar relacionado ao fato de os folhetos serem lidos e ouvidos, na maior parte dos casos, em voz alta e coletivamente, em reuniôes que congregavam parentes e vizinhos. Também nessas reuniões, como se viu, os contadores de histórias divertiam a platéia ao narrar, com habilidade, contos da tradição oral, e os cantadores eram presença constante. Desse modo, a prática de leitura de folhetos ocorria em um espaço em que circulavam, sem aparentes hierarquizaçōes, o oral e o escrito. A tendência "oral" dos poemas não deve ser vista, no entanto, sem ressalvas. Sabe-se que, nas décadas iniciais do século XX, no Brasil, de modo geral, a presença da oralidade é inerente à produção literária e, em especial, à poesia. A poesia era considerada, sobretudo, um gênero oral, escrita para ser 
recitada ou lida em voz alta, mesmo nos meios eruditos, a ponto de Antonio Cândido (1980), em seu conhecido ensaio, ter denominado o público leitor brasileiro da época como um público de auditores.

Entre o oral e o escrito também pareciam se situar as formas de apropriação da leitura dos folhetos. As leituras eram, sobretudo, realizadas de maneira intensiva: um mesmo poema era retomado sucessivamente, parecendo importar menos o conteúdo propriamente dito das histórias e mais o que elas eram capazes de suscitar no imaginário de cada leitor/ouvinte. Nesse processo, a memorização, facilitada pelas situações de leitura e pela própria estrutura narrativa e formal dos poemas, constituía um fator fundamental no processo de apropriação das histórias.

O estudo mostra, portanto, que, mesmo entre as camadas pouco escolarizadas e associadas ao mundo da oralidade, práticas de letramento eram vivenciadas, independentemente da escola, dos intelectuais, dos movimentos sociais organizados. A pesquisa mostra, ainda, como vários estudos têm buscado discutir, ${ }^{28}$ que são pouco complexas as análises que tendem a dicotomizar o oral e o escrito, atribuindo a essas duas dimensões constitutivas da cultura características que lhes seriam naturalmente inerentes. O que parece ocorrer, para usar a expressão de Bakhtin (1993), é uma circularidade entre os dois aspectos em uma mesma cultura, em uma mesma época, não parecendo existir nem um contínuo, nem uma progressão, nem uma hierarquização entre eles.

\section{Recebido e aprovado em outubro de 2002.}

\section{Notas}

1. Em 1920 e 1940, as taxas de analfabetismo entre a população com mais de 15 anos eram, respectivamente, de $69,9 \%$ e $56,2 \%$. Os índices de escolarização da população de 5 a 19 anos eram, no mesmo período, de 8,99\% e 21,43\%. (Romanelli, 1978, p. 62 e 64).

2. Para uma problematização mais detalhada dessas questôes, ver Batista et al. (2002).3. Como exemplo, podemos citar o já clássico estudo de Ginzburg (1991) e os casos pesquisados por Jean Hébrard (1996a e 1996b).

4. Tomo, aqui, a noção de "discurso" na perspectiva foucaultiana (ver Foucault, 1972).

5. Ver Michel de Certeau (1994).

6. Utilizo, neste texto, muitas vezes, a palavra "folheto" em lugar de "cordel" porque assim esse tipo de literatura era geralmente conhecido entre poetas, editores, folheteiros e leitores. A designação "literatura de cordel", até então utilizada para um tipo de literatura semelhante encontrado em Portugal, tem sua origem nos estudos acadêmicos sobre o 
tema, tendo sido adotada e difundida, por todo o país, a partir da década de 1960 (Cascudo, 1988).

7. A pesquisa resultou na tese de doutorado Lerlouvir folhetos de cordel em Pernambuco (1930-1950), orientada por Magda Soares e apresentada ao Programa de Pós-Graduação em Educação da UFMG em março de 2000; ver Galvão (2000). Uma versão reduzida do trabalho foi publicada em livro (Galvão, 2001a).

8. Edson nasceu em Limoeiro, agreste de Pernambuco, em 1921; vende folhetos de cordel desde 1938. Foi entrevistado para esta pesquisa em 1996 e 1997.

9. Zé Mariano, entrevistado em 1996 e 1997, nasceu em Umbuzeiro, Paraíba, em 1922. Trabalhou, inicialmente, como pequeno agricultor e, depois que migrou para o Recife, como pedreiro e em outras ocupações, principalmente na construção civil. Analfabeto, nunca freqüentou a escola.

10. Zeli, filha de Delita e irmã de Zezé, nasceu em Jaboatão, na região metropolitana do Recife, em 1930. Dona de casa, estudou até o "terceiro livro de leitura"; foi entrevistada em 1997.

11. Gonçalo Fernandes Trancoso publicou, em 1585, a primeira coletânea portuguesa de contos colhidos da tradição oral: Contos e histórias de proveito e exemplo. Segundo Câmara Cascudo (1988), os contos de Trancoso espalharam-se rapidamente: em 1618, na obra Diálogos das grandezas do Brasil, já há registros sobre eles na Capitania da Paraíba. De modo geral, a denominação "contos" ou "histórias de Trancoso" passou a designar, em alguns estados do Nordeste, todo o gênero de contos populares.

12. Crispim, casado com Ana Maria, nasceu em Sertânia, sertão de Pernambuco, em 1910. Trabalhou, durante a maior parte da vida, como pequeno agricultor. Em 1997, quando o entrevistei, morava há dois anos no Recife.

13. O depoimento de Zefinha não fez parte do corpus principal da pesquisa, tendo sido utilizado de forma secundária, pelo fato de a entrevistada ter nascido em 1965 (em Umbuzeiro, Paraíba).

14. As pessoas entrevistadas por Julie Cavignac (1997), em pesquisa realizada no sertão do Rio Grande do Norte, também confundiam as histórias de Trancoso, os contos e os romances de cordel. Percebe-se, como já têm apontado diversos estudos, que a questão das origens é extremamente problemática, principalmente em um país onde a circularidade entre culturas se encontra presente desde os momentos iniciais da colonização.

15. Ana Maria, dona de casa, casada com Crispim, nasceu também em Sertânia; foi entrevistada em 1997.

16. Antônio nasceu em Bezerros, agreste de Pernambuco, em 1925. Militar durante a maior parte de sua vida, há vários anos trabalha como ambulante no centro do Recife. Estudou até o "terceiro livro de leitura"; foi entrevistado em 1997.

17. Os entrevistados referiram-se, com freqüência, aos altos índices de analfabetismo característicos sobretudo das pequenas comunidades ou cidades onde moraram. Em Bezerros, cidade de um dos entrevistados, a taxa de analfabetismo entre os maiores de 5 anos chegava a $88,63 \%$ da população (IBGE, 1950).

18. Essa constatação já foi evidenciada em alguns estudos sobre o tema. Ver, por exemplo, Franklin Maxado (1984) e Antônio Arantes (1982).

19. Delita, mãe de Zezé e de Zeli, nasceu em Pilar, Paraíba, em 1911, e faleceu no Recife, em 2000. Desde os 16 anos morava em uma cidade da região metropolitana do Recife. Trabalhou a maior parte da vida como lavadeira; foi entrevistada em 1997.

20. Zezé, filha de Delita e irmã de Zeli, nasceu em Jaboatão, na região metropolitana do Recife, em 1932. Dona de casa, cursou os quatro primeiros anos da escola primária; foi entrevistada em 1997. 
21. Ver, por exemplo, Franklin Maxado (1984) e Marlyse Meyer (1980).

22. Esse comportamento parece caracterizar, em grande medida, os procedimentos autodidatas de aprendizagem da leitura: "Da alta idade média à época contemporânea, parece que existem assim os mesmos procedimentos 'selvagens' de acesso ao escrito, aí compreendido no interior das formas menos profissionalizadas da alfabetização. Todos participam do mesmo espírito: chegar a identificar no texto escrito os segmentos que correspondem a unidades mais ou menos bem recortadas de um texto oral já memorizado. Esse procedimento poderia caracterizar tanto uma alfabetização restrita (limitada ao corpus fechado dos textos anteriormente memorizados e referente essencialmente ao registro religioso) quanto uma alfabetização que pode generalizar-se para uma multiplicidade de leituras estranhas a essa cultura escrita de transmissão oral, que permanece sendo o ponto de partida de qualquer trajeto autodidático" (Hébrard, 1996b, p. 60).

23. Observe-se que a referência utilizada era o tempo de declamação e audição do folheto, já que a "leitora" era analfabeta, não recorrendo ao impresso, mas somente à sua memória.

24. Tipos semelhantes de alterações foram constatados por Julie Cavignac (1997), ao comparar os textos dos folhetos com as performances orais dos narradores: a memória das pessoas entrevistadas permanece, em muitos casos, fiel ao texto escrito, mas, às vezes, dele também se distancia, quando recria certas estrofes, não obedece à métrica e/ou utiliza um vocabulário próprio.

25. Utilizo, aqui, as expressōes "intensiva" e "extensiva” nos sentidos que lhes são atribuídos por Rolf Engelsing, em artigo datado de 1970, e retomado sucessivamente por historiadores da leitura. Ver, por exemplo, Roger Chartier e Guglielmo Cavallo (1997). Segundo a tese de Engelsing, na segunda metade do século XVIII, a leitura "intensiva" teria sido substituída por uma leitura qualificada de "extensiva": gradativamente, a leitura de um corpus limitado e fechado de textos (principalmente de cunho religioso), lidos e relidos, memorizados e recitados, transmitidos de geração em geração, passou a ser substituída pela leitura, rápida e ávida, de um grande número de impressos, diversos e efêmeros. Essa tese tem sido continuamente questionada, principalmente porque estudos mais recentes têm observado que numerosos eram os leitores "extensivos" na época considerada de leitura "intensiva". No entanto, mantêm-se os conceitos gerais dos dois tipos de leitura que, muitas vezes, ocorrem ao mesmo tempo e no mesmo espaço.

26. O barbaro crime das mattas da Varzea, assinado por João Martins de Athayde (Recife, 1928); Historia da princesa da Pedra Fina, assinado por João Martins de Athayde (Recife, 1944); A batalha de Oliveiros com Ferrabraz, assinado por João Martins de Athayde (Recife, 1946); O cachorro dos mortos, assinado por João Martins de Athayde (Recife, s.d.); A lamentável morte de Getúlio Vargas, sem autoria (s.1., 1954); O pavão misterioso, sem autoria (Recife, s.d.); A chegada de Lampião no inferno, assinado por José Pacheco (s.l., s.d.); As proezas de João Grilo, sem autoria (s.l., s.d.).

27. Por "índice de oralidade", Paul Zumthor (1993, p. 35) compreende "tudo o que, no interior de um texto, informa-nos sobre a intervençáo da voz humana em sua publicação - quer dizer, na mutação pela qual o texto passou, uma ou mais vezes, de um estado virtual à atualidade e existiu na atenção e na memória de certo número de indivíduos".

28. Por exemplo, Street (1995), Barton e Hamilton (1998) e Signorini (2001).

\section{Referências bibliográficas}

\section{ARANTES, A.A. O trabalho e a fala: estudo antropológico sobre os folhetos de cordel. São Paulo: Kairós; funCAMP, 1982.}


BAKHTIN, M. A cultura popular na Idade Média e no Renascimento: o contexto de François Rabelais. São Paulo: Hucitec, 1993.

BARTON, D.; HAMILTON, M. Local literacies: reading and writing in one community. London: Routledge, 1998.

BATISTA, A.A. et al. Entrando na cultura escrita: trajetórias individuais, familiares e sociais; séculos XIX e XX. Belo Horizonte; Recife, 2002. Projeto de pesquisa. (mimeo.)

CÂNDIDO, A. Literatura e sociedade: estudos de teoria e história literária. São Paulo: Nacional, 1980.

CASCUDO, L.C. Literatura oral no Brasil. 3 ed. Belo Horizonte: Itatiaia, 1984.

CASCUDO, L.C. Dicionário do folclore brasileiro. Belo Horizonte: Itatiaia, 1988.

CAVIGNAC, J. La litérature de colportage au Nord-Est du Brésil. Paris: CNRS, 1997.

CERTEAU, M. A invenção do cotidiano. Petrópolis: Vozes, 1994.

CHARTIER, R. Au bord de la falaise: l'histoire entre certitudes et inquietude Paris: A. Michel, 1998.

CHARTIER, R.; CAVALLO, G. (Dir.). Histoire de la lecture dans le monde occidental. Paris: Seuil, 1997. p. 7-46

ECO, U. Lector in fabula. São Paulo: Perspectiva, 1986.

EGAN, K. Literacy and the oral foundations of education. Havard Educational Review, Cambridge, Mass., v. 57, n. 4, p.445-472, nov. 1987.

FOUCAUlT, M. A arqueologia do saber. Petrópolis: Vozes, 1972.

GALVÃO, A.M.O. Lerlouvir folhetos de cordel em Pernambuco: 19301950. 2000. Tese (Doutorado) - Faculdade de Educação. Universidade Federal de Minas Gerais, Belo Horizonte.

GALVÃO, A.M.O. Cordel: leitores e ouvintes. Belo Horizonte: Autêntica, 2001a.

GALVÃO, A.M.O. Processos de inserção de analfabetos e semi-alfabetizados no mundo da cultura escrita. Revista Brasileira de Educação, Belo Horizonte, n. 16, jan./abr. 2001b. 
GINZBURG, C. O queijo e os vermes: o cotidiano e as idéias de um moleiro perseguido pela inquisição. São Paulo: Companhia das Letras, 1991.

HAVELOCK, E. The coming of literate communication to western culture. In: Kintgen, E.R.; Kroll, B.M.; Rose, M. Perspectives on literacy. Carbondale: Southern Illinois University, 1988. p. 127-134.

HAVELOCK, E. A equação oralidade-cultura: uma fórmula para a mente moderna. In: Olson, D.R.; Torrance, N. (Orgs.). Cultura escrita e oralidade. São Paulo: Ática, 1995. p. 17-34.

HÉBRARD, J. Alphabétisation et accès aux pratiques de la culture écrite en Vaunage à la fin du XIXe. siècle: étude de cas. In: Roger, J.M. (Dir.). La Vaunage au XIXe siècle: approche économique, sociale et politique d'une communauté paysanne de la région nîmoise. Nimes: C. Lacour, 1996a.

HÉBRARD, J. O autodidatismo exemplar: como Jamerey-Duval aprendeu a ler? In: Chartier, R. (Org.). Práticas da leitura. São Paulo: Estação Liberdade, 1996b. p. 35-74.

INSTITUTO BRASILEIRO DE GEOGRAFIA E ESTATISTICA. Recenseamento Geral do Brasil (10 de setembro de 1940). Censos demográficos: população e habitação. Rio de Janeiro: IBGE, 1950. (Série Regional, parte IX - Pernambuco, t.1)

LORD, A.B. The singer of tales. Cambridge, Mass.: Havard University, 1960 .

MACHADO, I.A. O romance e a voz: a prosaica dialógica de Mikhail Bakhtin. Rio de Janeiro: Imago; São Paulo: FAPESP, 1995.

MAXADO, F. O cordel televivo: futuro, presente e passado da literatura de cordel. Rio de Janeiro: Codecri, 1984.

MEYER, M. Autores de cordel. São Paulo: Abril Cultural, 1980.

ONG, W.J. The orality of language. In: ONG, W.J. Orality and literacy: the technologizing of the world. London: Methuen, 1982. p. 5-15;31-77.

PROENÇA, I.C. A ideologia do cordel. 2. ed. Rio de Janeiro: Imago, 1977. 
ROMANELLI, O.O. História da educação no Brasil. Petrópolis: Vozes, 1978.

SIGNORINI, I. (Org.). Investigando a relação orallescrito e as teorias do letramento. Campinas: Mercado de Letras, 2001.

SOARES, M.B. Letramento: um tema em três gêneros. Belo Horizonte: Autêntica, 1998.

STREET, B.V. Social literacies: critical approaches to literacy in development, ethnography and education. London; New York: Longman, 1995.

ZUMTHOR, P. A letra e a voz: a "literatura" medieval. São Paulo: Companhia das Letras, 1993.

Folhetos citados

ATHAYDE, J.M. Historia da princesa da Pedra Fina. Recife: João Martins de Athayde, 1944. 32p. (Acervo da Fundação Casa de Rui Barbosa - Rio de Janeiro - RJ)

ATHAYDE, J.M. Batalha de Oliveiros com Ferrabraz. Recife: João Martins de Athayde, 1946. 32p. (Acervo da Fundação Casa de Rui Barbosa - Rio de Janeiro - RJ)

ATHAYDE, J.M. O cachorro dos mortos. Recife: João Martins de Athayde, [19-]. 40p. (Acervo da Fundação Casa de Rui Barbosa Rio de Janeiro - RJ)

O BARBARO crime das mattas da Varzea. Recife: João Martins de Athayde, 1928. 8p. (Fonds Raymond Cantel - Poitiers - França)

A LAMENTÁVEL morte de Getúlio Vargas. [ s.l.: s.n], 1954. 8p. (Fonds Raymond Cantel - Poitiers - França)

PACHECO, J. A chegada de Lampião no inferno. [ s.l.: s.n., 19-]. 8p. (Acervo da Fundação Casa de Rui Barbosa - Rio de Janeiro - RJ)

O PAVÃO misterioso. Recife: [s.n., 19-]. 32p. (Acervo da Fundação Casa de Rui Barbosa - Rio de Janeiro - RJ)

AS PROEZAS de João Grilo. [s.l.: s.n., 19-]. 34p. (Acervo da Fundação Casa de Rui Barbosa - Rio de Janeiro - RJ) 